\title{
Pembelajaran Sejarah di SMK era revolusi industri 4.0: tantangan dan peluang
}

\author{
Nur Fajar Absor ${ }^{1}$, Umasih ${ }^{2}$, Kurniawati ${ }^{3}$ \\ Diterima 29 Juli 2019, Dipublikasikan 31 Oktober 2019 \\ Cpenulis (2019)
}

\begin{abstract}
Vocational High Schools (VHS) are currently facing challenges in the era of Industrial Revolution 4.0, this is responded by the government by issuing one of the regulations, namely Peraturan Dirjen Dikdasmen No. 07/D.D5/KK/2018 which changes the curriculum structure in VHS. One of the subjects affected is Sejarah Indonesia which currently only gets 3 hours in class X. Though history is important to learn for show its identity as a nation. The purpose of this study is to examine the challenges and opportunities that faced on history learning in VHS at the era of Industrial Revolution 4.0, so that the application of history learning becomes effective and efficient. This study uses qualitative method by conducting interviews with four teachers and documents study about regulations of curriculum and reviewing other studies. The results found that teachers can use technology in learning, such as Whatsapp, Instagram, Edmodo, Prezi, documentary films, and visit local cultural heritage sites and museums as a media and source of history learning, so that can also be delivered effectively and efficiently. Finally, the goal of history learning to show its identity as a nation and also the integration of Indonesian nation can remain in the midst at the era of Industrial Revolution 4.0.
\end{abstract}

Keywords

History Learning, National Identity, National Integration

\section{PENDAHULUAN}

Sekolah Menengah Kejuruan (SMK) merupakan salah satu jenjang di dalam pendidikan formal yang ada di Indonesia untuk mempersiapkan peserta didik, terutama bekerja dalam bidang tertentu (Undang-Undang Nomor 20 Tahun 2003). SMK saat ini menghadapi suatu tantangan berat ketika berkaitan dengan era Revolusi Industri 4.0. Schwab (dalam Ghufron, 2018) menjelaskan bahwa Revolusi Industri 4.0 secara mendasar mengubah individu dalam cara hidup, bekerja, dan berhubungan satu sama lain. Perubahan tersebut sangat dramatis dan terjadi pada kecepatan eksponensial. Berbeda dengan Revolusi Industri sebelumnya, Revolusi Industri 4.0 ditandai dengan berkembangnya Internet of Things yang diikuti dengan teknologi baru dalam data sains, kecerdasan buatan, robotik, penyimpanan data dalam cloud, cetak 3D, dan teknologi nano (Ghufron, 2018).

Hal tersebut bertambah pelik, ketika di era Revolusi Industri 4.0 ini penggunaan robot semakin masif untuk menggantikan tenaga manusia dengan pertimbangan efektivitas dan

1 Program Magister Pendidikan Sejarah, Universitas Negeri Jakarta nurfajar_ps17s2@mahasiswa.unj.ac.id

2 Program Magister Pendidikan Sejarah, Universitas Negeri Jakarta umasih@unj.ac.id

3 Program Magister Pendidikan Sejarah, Program Pascasarjana, Universitas Negeri Jakarta kurniawati@unj.ac.id 
efisiensi. Sehingga, timbullah permasalahan baru, yaitu meningkatnya jumlah pengangguran yang saat ini berjumlah 7 juta orang. Dilihat dari tingkat pendidikannya, lulusan yang berasal dari SMK menduduki peringkat teratas dalam jumlah pengangguran, yakni sebesar 11,24\% (786.800 orang) (Badan Pusat Statistik, 2018). Maka dari itu, diperlukan inovasi di dalam SMK dengan melihat berbagai macam perubahan yang terjadi di era Revolusi Industri 4.0.

Di tingkat nasional, pemerintah Indonesia dalam hal ini Direktur Jenderal Pendidikan Dasar dan Menengah, Kementerian Pendidikan dan Kebudayaan mengeluarkan peraturan baru yang menetapkan Spektrum Keahlian di lingkungan Pendidikan Menengah Kejuruan (SMK/MAK) yang sejalan dengan tuntutan perkembangan kurikulum, iptek, seni, dinamika perkembangan global, dan kebutuhan dunia kerja saat ini (Peraturan Direktur Jenderal Pendidikan Dasar dan Menengah Nomor 06/D.D5/KK 2018).

Menindaklanjuti hal tersebut, dikeluarkan pula Peraturan Dirjen Dikdasmen No. 07/D.D5/KK/2018 yang mengubah struktur mata pelajaran di lingkungan Pendidikan Menengah Kejuruan. Mata pelajaran Sejarah Indonesia untuk lingkungan Pendidikan Menengah Kejuruan mengalami perubahan yang signifikan, yakni hanya mendapatkan 3 jam pelajaran di kelas X saja yang sebelumnya diberikan 2 jam pelajaran untuk semua jenjang kelas, yakni kelas X-XII. Hal ini berbeda dengan struktur mata pelajaran yang ada di lingkungan Pendidikan Menengah Umum (SMA/MA) yang mempelajarinya dari kelas X-XII dengan durasi waktunya adalah 2 jam pelajaran di masing-masing jenjang kelas.

Padahal, mata pelajaran Sejarah Indonesia butuh dipelajari untuk menunjukkan identitasnya sebagai suatu bangsa di tengah-tengah era Revolusi Industri 4.0 yang saat ini dihadapi. Hal ini sejalan dengan pendapat Naredi (2016) yang menyampaikan bahwa pembelajaran sejarah memiliki tujuan untuk mengenalkan karakteristik dan identitas bangsanya dalam rangka membentuk suatu nation and character building dan menjadi sumber inspirasi tumbuhnya sense of pride (rasa kebanggaan) dan sense of obligation (rasa kewajiban) terhadap bangsa dan negaranya.

Lebih lanjut lagi, identitas tersebut menjadikan sebuah bangsa bersatu dan mewujudkan integrasi nasional. Dengan mempelajari sejarah, nantinya akan tumbuh rasa cinta dan kebanggaan terhadap Indonesia yang dampak jangka panjangnya adalah integrasi nasional bangsa Indonesia dapat tetap terjaga (Gunawan, 2016). Oleh karena itu, berdasarkan pemaparan dari Naredi dan Gunawan di atas, maka mata pelajaran Sejarah Indonesia di SMK tetap penting dipelajari di era Revolusi Industri 4.0 yang saat ini dihadapi, yakni untuk menunjukkan identitasnya sebagai suatu bangsa hingga akhirnya integrasi nasional bangsa Indonesia dapat tetap terjaga.

Meskipun terdapat tantangan dengan munculnya Peraturan Dirjen Dikdasmen No. 07/D.D5/KK/2018, namun terdapat peluang di dalamnya untuk menerapkan pembelajaran sejarah secara efektif dan efisien. Hal tersebut yang menjadi tujuan dari penelitian ini, yakni untuk menguraikan tantangan dan peluang yang dihadapi dalam pembelajaran sejarah di SMK era Revolusi Industri 4.0, sehingga penerapan pembelajaran tersebut menjadi efektif dan efisien. Sejauh ini, belum ada penelitian mengenai pembelajaran sejarah di SMK berdasarkan struktur kurikulum yang baru, yakni Peraturan Dirjen Dikdasmen No. 07/D.D5/KK/2018. Oleh karena itu, penelitian ini diharapkan menjadi pionir bagi penelitian berikutnya untuk mengkaji lebih dalam pembelajaran di SMK dari berbagai macam aspek. 


\section{METODE}

Penelitian ini menggunakan metode kualitatif. Sedangkan, teknik pengumpulan datanya menggunakan instrumen wawancara dan studi dokumen atau dokumentasi (Sugiyono, 2015; Wirawan, 2016). Wawancara dilakukan terhadap empat orang guru yang ada di Jakarta dan Bekasi, selain itu peneliti juga melakukan studi dokumen dengan mengkaji peraturan-peraturan mengenai kurikulum yang ada di SMK, kemudian peneliti juga mengkaji penelitian-penelitian lainnya yang berkaitan dengan fokus penelitian mengenai pembelajaran sejarah di SMK era Revolusi Industri 4.0.

Sedangkan, untuk teknik analisis datanya, peneliti menggunakan model Miles dan Huberman (dalam Sugiyono, 2015) dengan tahapan-tahapannya sebagai berikut: (1) Reduksi data merupakan kegiatan merangkum, memilih, dan memfokuskan pada hal-hal yang penting untuk kemudian dicari tema dan polanya, dan selanjutnya membuang hal-hal yang tidak perlu; (2) Penyajian data adalah aktivitas ketika data yang sudah direduksi sebelumnya diorganisasikan dan disusun dalam pola hubungan, sehingga peneliti akan semakin mudah memahami data-data yang sudah didapatkan selama penelitian; (3) Kesimpulan atau Verifikasi, yakni tahapan akhir ketika temuan yang didapatkan menjawab rumusan masalah atau tujuan yang dikemukakan sejak awal, sehingga suatu obyek penelitian yang sebelumnya masih remang-remang atau gelap menjadi jelas setelah dilakukan suatu penelitian.

\section{HASIL DAN PEMBAHASAN}

Merujuk kepada struktur kurikulum yang ada di SMK berdasarkan Peraturan Dirjen Dikdasmen No. 07/D.D5/KK/2018, maka mata pelajaran Sejarah Indonesia mendapatkan alokasi waktu yang lebih sedikit dibandingkan dengan mata pelajaran lainnya yang masuk ke dalam kelompok Muatan Nasional, yakni hanya mendapatkan 108 jam mata pelajaran. Lebih rinci lagi, mata pelajaran Sejarah Indonesia di SMK hanya dipelajari di kelas X saja dengan alokasi waktunya sebanyak 3 jam pelajaran, berbeda dengan mata pelajaran lainnya yang masuk ke dalam kelompok Muatan Nasional yang dipelajari dari kelas X sampai kelas XII, seperti yang dapat dilihat dalam Gambar 1.

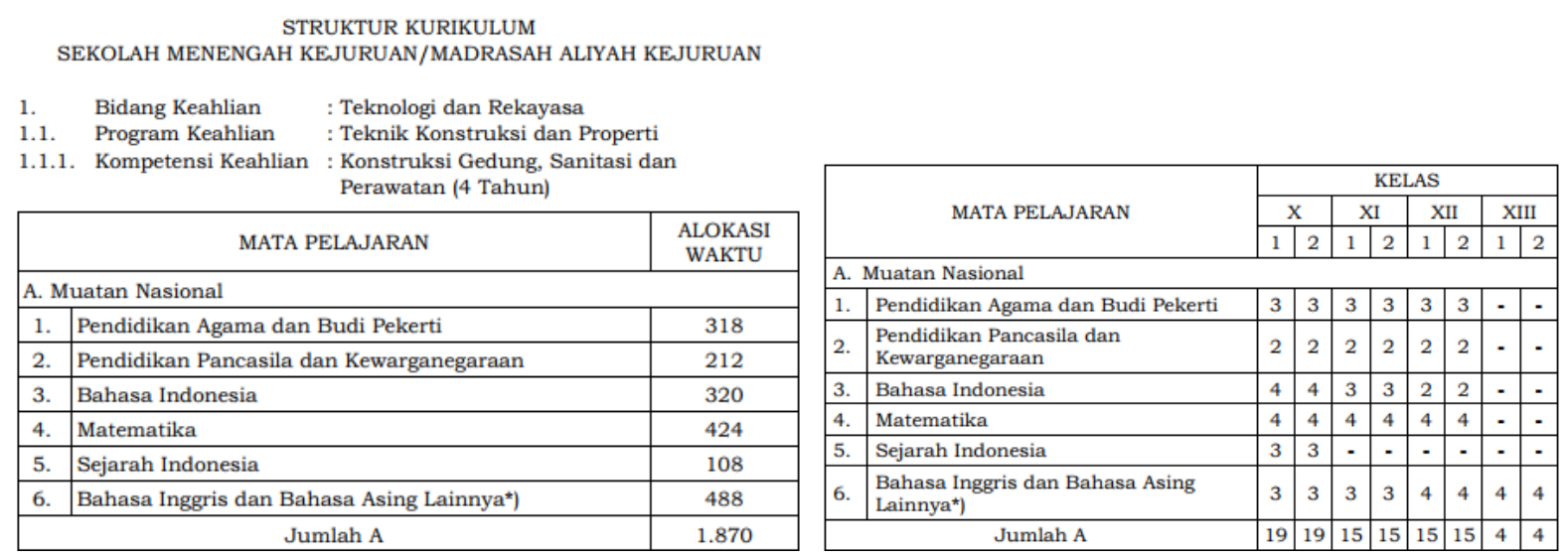

Gambar 1. Struktur Kurikulum SMK/MAK Berdasarkan Peraturan Dirjen Dikdasmen No. 07/D.D5/KK/2018

Sumber: Peraturan Dirjen Dikdasmen No. 07/D.D5/KK/2018

Kemudian, menjadi tantangan baru lagi di dalam pembelajaran sejarah di SMK ketika dilihat dari segi materinya, terjadi pemadatan materi pada mata pelajaran Sejarah Indonesia di kelas 
$\mathrm{X}$. Hal ini bisa dilihat dari materinya yang dimulai dari "memahami konsep dasar sejarah" hingga materi "mengevaluasi kehidupan Bangsa Indonesia dalam mengembangkan ilmu pengetahuan dan teknologi pada era kemerdekaan" (Peraturan Direktur Jenderal Pendidikan Dasar dan Menengah Kementerian Pendidikan dan Kebudayaan Nomor 464/D.D5/KR/2018). Padahal, materi tersebut tersebar di dalam mata pelajaran Sejarah Indonesia kelas X sampai kelas XII di lingkungan Pendidikan Menengah Umum.

Pemadatan materi tersebut membuat guru mengejar penyelesaian materi dalam pembelajarannya. Selain itu, dengan waktu yang padat juga membuat guru kesulitan dalam melakukan penilaian, terutama dalam program remedial. Tantangan lainnya adalah buku paket yang sesuai dengan struktur mata pelajaran tersebut baru ada pada bulan Januari 2019, adapun buku tersebut diterbitkan oleh penerbit swasta, bukan dari Kemendikbud sendiri. Selanjutnya, ketika peserta didik naik ke jenjang kelas XII, mata pelajaran Sejarah Indonesia dimasukkan ke dalam USBN (Ujian Sekolah Berbasis Nasional), sementara mata pelajaran tersebut hanya dipelajari di Kelas X (LI, 2019; RG, 2019; S, 2019; DP, 2019).

Meskipun demikian, dengan masifnya perkembangan internet saat ini membuka kesempatan bagi guru untuk memanfaatkannya sebagai media dalam pembelajaran, sehingga efektif dan efisien ketika melakukan kegiatan pembelajaran. Beberapa media berbasis internet yang bisa digunakan oleh guru di antaranya adalah (1) Membuat grup kelas di Whatsapp atau Line; (2) Mengakses Facebook atau Instagram; (3) Membuka kelas online di Google Classroom atau Edmodo. Selain itu, guru juga dapat memanfaatkan media lainnya yang bukan berbasis internet, namun menarik untuk digunakan, seperti (1) Presentasi menggunakan Prezi atau Imindmap; (2) Menonton film atau video dokumenter; (3) Mengunjungi situs cagar budaya atau museum setempat. (LI, 2019; RG, 2019; DP, 2019).

Permasalahan mengenai guru yang mengejar penyelesaian materi dalam pembelajarannya menimbulkan suatu kekhawatiran bahwa nantinya peserta didik hanya sekadar menghafal nama tokoh dan peristiwa pada masa lalu, padahal paradigma tersebut keliru. Hal ini disampaikan oleh Naredi (2016) bahwa mempelajari sejarah bangsa tidak hanya sekadar menghafal nama tokoh dan tahun kejadian di masa lampau, akan tetapi belajar tentang pengalaman generasi di masa lampau untuk diambil hikmahnya dan dijadikan sebagai titik tolak untuk membangun masa depan yang lebih baik. Sehingga, apabila hanya mengejar penyelesaian materi tersebut, tujuan dari pembelajaran sejarah untuk menunjukkan identitasnya sebagai suatu bangsa di tengah-tengah era Revolusi Industri 4.0 yang saat ini dihadapi menjadi suatu tantangan tersendiri.

Meski demikian, dengan adanya tantangan tersebut, muncul peluang-peluang dalam melaksanakan pembelajaran sejarah di SMK era Revolusi Industri 4.0 secara efektif dan efisien, terutama pemanfaatan internet sebagai media pembelajaran. Berbagai media berbasis internet yang telah diuraikan sebelumnya, sejalan dengan berbagai penelitian yang sudah dipublikasikan selama ini.

Terkait dengan pembuatan grup kelas di Whatsapp, hasil penelitian Kartikawati dan Pratama (2017) dan Purnomo, Kurniawan dan Aristin (2019) menunjukkan bahwa hal tersebut efektif untuk diterapkan dalam proses pembelajaran sebagai upaya untuk meningkatkan kemampuan berpikir kritis peserta didik secara mandiri. Hal ini bisa dikembangkan lagi oleh guru bahwa pembuatan grup kelas di Whatsapp tersebut tidak hanya sekadar membuat grup kelas, tetapi bisa memuat beberapa link website yang membahas mengenai sejarah, seperti historia.id dan tirto.id. 
Selanjutnya, berkaitan dengan mengakses Instagram, berdasarkan penelitian Utami, dkk. (2015) menyatakan bahwa penggunaan Instagram sebagai media pembelajaran dapat membantu meningkatkan kemampuan berpikir kreatif peserta didik. Hal tersebut dapat dikembangkan lagi oleh guru bahwa penggunaan Instagram dapat dimanfaatkan peserta didik untuk mengakses akun-akun yang membahas mengenai sejarah, seperti Kelompok Pemerhati Budaya dan Museum Indonesia (KPBMI) dan Album Sejarah.

Lalu, terkait dengan pembukaan kelas online di Edmodo, penelitian yang dilakukan oleh Cahyono (2015) menunjukkan bahwa Edmodo bisa dijadikan sebagai media pembelajaran untuk mengurangi atau menghindari terlambatnya pendidikan nilai yang disampaikan dalam proses pembelajaran, karena kelas online tersebut dijadikan sarana untuk memudahkan pemberian materi pembelajaran dan pengumpulan tugas oleh guru.

Selain penggunaan internet, terdapat berbagai media lainnya yang bisa dimanfaatkan sebagai media atau sumber pembelajaran sejarah yang telah disampaikan sebelumnya, senada dengan berbagai penelitian yang telah dipublikasikan selama ini. Terkait dengan guru yang menyampaikan materi pembelajaran melalui presentasi menggunakan Prezi, berdasarkan penelitian Saputri dkk. (2016) menyimpulkan bahwa media presentasi Prezi dapat digunakan sebagai alat bantu guru dalam pembelajaran di kelas untuk meningkatkan motivasi belajar peserta didik. Meskipun penelitian ini dilakukan pada mata pelajaran Akuntansi, namun bisa dijadikan rujukan untuk menerapkannya pada mata pelajaran Sejarah Indonesia dengan berbagai macam modifikasi di dalamnya.

Kemudian, terkait dengan menonton film atau video dokumenter, penelitian Prananda dkk. (2018) mengemukakan bahwa penggunaan media film dokumenter sebagai sumber belajar cukup efektif untuk meningkatkan minat belajar siswa terhadap mata pelajaran sejarah. Penggunaan media film dokumenter ini juga membantu guru dalam menyampaikan materi pembelajaran secara efektif dan efisien, sehingga guru tidak harus menyampaikan materi pembelajarannya secara konvensional (ceramah) saja.

Terakhir, terkait dengan kunjungan ke situs cagar budaya atau museum setempat dapat dilakukan ketika di luar jam pelajaran. Berdasarkan penelitian-penelitian yang sudah ada menunjukkan bahwa situs cagar budaya atau museum dapat dijadikan sebagai sumber belajar sejarah bagi para peserta didik ketika mereka berkunjung ke sana. Suswandari (2017) dan Bayu Kurniawan, dkk (2019) menyimpulkan bahwa berbagai situs cagar budaya dan museum, seperti Benteng, Masjid Agung, dan Museum yang bisa dimanfaatkan sebagai pendidikan berbasis objek bersejarah yang juga bisa dijadikan sebagai sumber belajar. Lalu, A. dkk. (2018) berkesimpulan bahwa terdapat berbagai museum di Jakarta, seperti Museum Kebangkitan Nasional, Museum Sumpah Pemuda, dan Museum Perumusan Naskah Proklamasi yang dapat digunakan sebagai sumber belajar sejarah. Selain itu, penelitian Naredi dkk. (2018) juga menyimpulkan bahwa Museum Kota Makassar dapat dijadikan sebagai alternatif sumber belajar.

Dengan demikian, pembelajaran sejarah dapat disampaikan oleh guru secara efektif dan efisien dengan menggunakan teknologi yang ada saat ini. Sehingga, tujuan pembelajaran sejarah yang berhubungan dengan identitas dan integrasi nasional suatu bangsa dapat dilaksanakan di tengah himpitan Revolusi Industri 4.0 saat ini. Hal ini sesuai dengan pendapat Suswandari dan Absor (2018) bahwa pembelajaran sejarah dapat mengembangkan dan 
memperkuat sifat, karakter, dan identitas generasi muda di tengah-tengah kehidupan global saat ini.

\section{SIMPULAN}

Permasalahan terkait dengan pengurangan jam mata pelajaran Sejarah Indonesia di SMK yang juga berimbas kepada padatnya materi yang dipelajari menjadi suatu tantangan tersendiri di dalam pembelajaran sejarah di SMK. Namun, terdapat peluang di dalamnya ketika guru dapat memanfaatkan teknologi, terutama internet di era Revolusi Industri 4.0 saat ini, mulai dari penggunaan Whatsapp, Instagram, Edmodo, Prezi, film atau video dokumenter, hingga yang terakhir adalah mengunjungi situs cagar budaya dan museum setempat.

Pembelajaran sejarah pun dapat disampaikan secara efektif dan efisien, meskipun terjadi pengurangan jam dan pemadatan materi di dalam mata pelajaran Sejarah Indonesia. Oleh karena itu, tujuan pembelajaran sejarah, terutama di lingkungan SMK, yakni untuk menunjukkan identitasnya sebagai suatu bangsa hingga akhirnya integrasi nasional bangsa Indonesia dapat tetap terjaga di tengah-tengah era Revolusi Industri 4.0 yang saat ini dihadapi.

Diharapkan pada penelitian berikutnya, perlu dikembangkan penelitian untuk melihat keefektifan pembelajaran langsung (tatap muka) secara terus-menerus, karena ada kecenderungan bahwa pembelajaran secara terus-menerus lebih baik daripada pembelajaran yang hanya diadakan sekali saja, misalnya di SMK mata pelajaran Sejarah Indonesia hanya dipelajari di kelas X, akan lebih baik lagi apabila mata pelajaran Sejarah Indonesia dipelajari dari kelas X sampai kelas XII, supaya peserta didik lebih memahami mata pelajaran Sejarah Indonesia dengan baik dan tujuan dari pembelajaran sejarah dapat tercapai lebih baik lagi.

\section{DAFTAR PUSTAKA}

Badan Pusat Statistik (2018) Keadaan Ketenagakerjaan di Indonesia 2018. Jakarta.

Bayu Kurniawan, Idris, Agus Purnomo, Agung Wiradimadja, S. (2019) 'Using Broadcasting Learning Design to Enhance Student's Experiential Skill - Learning \& Technology Library (LearnTechLib)', International Association of Online Engineering, Kassel, Germany, pp. 172-180. Available at: https://www.learntechlib.org/p/210531/ (Accessed: 29 October 2019).

Cahyono, Y. D. (2015) 'E-Learning (Edmodo) sebagai Media Pembelajaran Sejarah', Jurnal Penelitian, 18(2), pp. 102-112.

Ghufron, M. A. (2018) 'Revolusi industri 4.0: Tantangan, Peluang dan Solusi Bagi Dunia Pendidikan', in Seminar Nasional dan Diskusi Panel Multidisiplin Hasil Penelitian dan Pengabdian kepada Masyarakat, pp. 332-337.

Gunawan, R. (2016) 'Menjaga Integrasi Nasional dari Ancaman Dalam dan Luar Negeri melalui Pendidikan Sejarah', in Seminar Nasional dan Kongres Hispisi 2016. Jakarta: Universitas Negeri Jakarta, pp. 232-250.

Kartikawati, S. and Pratama, H. (2017) 'Pengaruh Penggunaan WhatsApp Messenger Sebagai Mobile Learning Terintegrasi Metode Group Investigation Terhadap Kemampuan Berpikir Kritis', Jupiter (Jurnal Pendidikan Teknik Elektro), 2(2), pp. 33-38. doi: 10.25273/jupiter.v2i2.1797.

Maulana Yusuf; Ibrahim, N. K. (2018) 'Pemanfaatan Museum sebagai Sumber Belajar dalam Pembelajaran Sejarah', Visipena, 9(2), pp. 215-235. 
Naredi, H. (2016) 'Membangun Karakter dan Jatidiri Bangsa Indonesia Melalui Pendidikan Sejarah', in Seminar Nasional Pendidikan Ilmu-Ilmu Sosial Membentuk Karakter Bangsa dalam Rangka Daya Saing Global. Makassar: Universitas Negeri Makassar dan Himpunan Sarjana Pendidikan Ilmu-Ilmu Sosial Indonesia, pp. 355-364.

Naredi, H., Qodariah, L. and Andi (2018) 'Pengenalan Museum Sebagai Informasi Kesejarahan Dalam Meningkatkan Kesadaran Sejarah', in Prosiding Kolokium Doktor dan Seminar Hasil Penelitian Hibah. Jakarta: Universitas Muhammadiyah Prof. DR. HAMKA, pp. 165-176. doi: https://doi.org/10.22236/psd/11165-17669.

Prananda, M. N., Sarkadi, S. and Ibrahim, N. (2018) 'Efektivitas Sumber Pembelajaran Sejarah', Jurnal Pendidikan Sejarah, 7(2), pp. 67-84. doi: 10.21009/jps.072.04.

Purnomo, A., Kurniawan, B. and Aristin, N. (2019) 'Motivation to Learn Independently through Blended Learning', in th International Conference on Educational Research and Innovation (ICERI 2018). Yogyakarta: Atlantis Press. doi: 10.2991/iceri-18.2019.55.

Saputri, I. J., Irafahmi, D. T. and Sumadi, S. (2016) 'Media Presentasi Prezi Pada Mata Pelajaran Akuntansi Untuk Meningkatkan Motivasi Belajar Siswa', Journal of Accounting and Business Education, 2(4). doi: 10.26675/jabe.v2i4.6075.

Sugiyono (2015) Metode Penelitian Pendidikan (Pendekatan Kuantitatif, Kualitatif, dan $R \& D)$. Bandung: Alfabeta.

Suswandari; Absor, N. F. (2018) 'The 21st Century of History Learning', in The $3 \mathrm{rd}$ International Seminar on Social Studies and History Education (ISSSHE) 2018. Bandung: Universitas Pendidikan Indonesia, pp. 84-90.

Suswandari, S. (2017) 'Ternate Historical Site as an Object Based Education for Sustainable Development', JETL (Journal Of Education, Teaching and Learning), 2(2), pp. 151-163. doi: $10.26737 /$ jetl.v2i2.279.

Utami, R. P., Probosari, R. M. and Fatmawati, U. M. I. (2015) 'Pengaruh Model Pembelajaran Project Based Learning Berbantu Instagram Terhadap Kemampuan Berpikir Kreatif Siswa Kelas X SMA Negeri 8 Surakarta The Effect of Project-Based Learning Models by Instagram Toward Creative Thingking of The Tenth Grade Students A', Jurnal Bio-Pedagogi, 4(1), pp. 47-52.

Wirawan (2016) Evaluasi: Teori, Model, Metodologi, Standar, Aplikasi dan Profesi. Jakarta: Rajawali Pers. 